\title{
A critical assessment of Anton Szandor LaVey's Philosophy OF INDULGENCE AS A DOGMA BASED ASSAULT ON SCRIPTURE
}

\begin{abstract}
Authors:
Simon Muwowo ${ }^{1}$

Johan Buitendag ${ }^{1}$
\end{abstract}

\section{Affiliations:}

${ }^{1}$ Department of Dogmatics

and Christian Ethics,

University of Pretoria,

South Africa

\section{Correspondence to:}

Johan Buitendag

email:

johan.buitendag@up.ac.za

Postal address:

Department of Dogmatics and Christian Ethics,

Faculty of Theology,

University of Pretoria,

Pretoria 0002, South Africa

\section{Keywords:}

philosophy; indulgence; moral agency; theology of nature

\section{Dates:}

Received: 25 Aug. 2010

Accepted: 17 Nov. 2010

Published: 08 Dec. 2010

How to cite this article: Muwowo, S. \& Buitendag, J., 2010, 'A critical assessment of Anton Szandor LaVey's Philosophy of Indulgence as a dogma based assault on Scripture', Verbum et Ecclesia 31(1), Art. \#428, 7 pages.

DOI: $10.4102 /$ ve.v31i1.428

This article is available at:

http://www.ve.org.za

Note:

This article is based on a thesis that was presented as partial fulfillment of the requirements for the degree MA (Dogmatics) in 2009 at the University of Pretoria, completed by the first author under the supervision of Prof. Dr Johan Buitendag.

(C) 2010. The Authors. Licensee: OpenJournals Publishing. This work is licensed under the Creative Commons Attribution License.

\begin{abstract}
The aim of this article has been to critically assess and unmask Anton Szandor LaVey's Philosophy of Indulgence reflected in The Satanic Bible (1969) as a dogma based assault on Scripture. The main task of this article has been to expose some contemporary ethical and dogmatic utterances used to express disagreements which LaVey alludes to in The Satanic Bible against Scripture. The debate in which these disagreements are expressed is their interminable character of the concept of what defines human morality. The philosophy under review has been assessed according to its effects on humanity. Does it create a just world and a set of values in the same way Scripture does or does it create unity of purpose or divergent views that put the world and the church on crossroads? The conclusion of this work posits a challenge towards evaluating the theology of nature, which now appears to be the main theological framework of the 21st century debate.
\end{abstract}

\section{INTRODUCTION AND DEFINITION OF TERMS}

A dogmatics of assault reflected in this article consists of teachings that seek to impinge Scripture negatively through philosophies that affect people's values and perceptions of religion and the world. One of the 20th century pioneers of such dogmatics of assault is Anton Szandor LaVey (1937-1997), the founder of the Church of Satan in the United States of America in May 1966. In 1969, LaVey wrote a worldly oriented book called The Satanic Bible (1969), a radical contrast to the Christian Bible. The basic argument that underlies The Satanic Bible is the Philosophy of Indulgence. This philosophy entails that human beings are not aliens in the world, but that they are created to be involved in every aspect of the world without any theoretical or moral captivity. In this, LaVey alludes to the fact that to be a Christian or to be of some other faith makes boundaries to the enjoyment of life hypocritical (LaVey 1969:21-22). Therefore, human beings must do that which can satisfy their life to the full, celebrating their bodies as objects of pleasure and indulge in any action of choice in order to attain the true meaning of life. LaVey considers the biblical Satan as a symbol of such values and choices. From the onset it is important to note that the word indulgence which dominates this article is not a word that is commonly used in theology except when we refer to the papal indulgence in the Roman Catholic Church, which all together carries a different meaning. This particular indulgence under assessment in this article is a philosophy of choices done in response to nature. This understanding may have very little relevance to traditional Christian dogmatics, but it is still a valid level of engagement with systematic theology.

\section{METHODOLOGY}

My approach in this study begins by examining LaVey's philosophical discourse which is derived in the daily experience of human life (LaVey 1969:50). This considers the questions people ask about God to relate to their daily existence and therefore strive towards an empirical theology based on human experiences. This work basically pursues LaVey's main Philosophy of Indulgence driven by the experience of his own life as a player of the calliope and organ for the bawdy shows on Saturday nights at the carnival, as well as for tent Evangelists on Sunday mornings where the same Christians lusting after women at the carnival came to church with their wives and children confessing their sins before God. With this observation, LaVey concluded that the Christian church (not individual Christians) thrives on hypocrisy and that a man's carnal lust (nature) prevails (LaVey 1969:7)! It is this conclusion that provided a firm, earthly background for evolving a cynical worldview that was mainly concerned in regarding human beings as subjects and objects of their own human choices.

In my assessment of LaVey's Philosophy of Indulgence as a dogma based assault on Scripture, I consider the value of indulgence from a socio-biological point of view with tangent points to the kingdom of God. I shall attempt to raise an academic debate between LaVey and Moltmann with regard to their understanding of life to provide a basis for wholeness. My point of departure views nature as a reality without any superficial interference (Nietzsche 1979:5-7). This argument is interwoven in the majority of my assessment of LaVey's philosophy developed in this article. Previous theories and philosophies will be tested in modern spheres and new possibilities will be raised. These possibilities are subjected to scrutiny in order to provide a sound theological and ethical view which the church can uphold with Scripture, as the ultimate authority.

\section{THE ARGUMENT}

My argument is that LaVey offers a concept of indulgence that is neither exclusively transcendental, nor anthropologically based. The exclusively transcendent aspect of indulgence is not relevant to the real experiences that people have. I argue that his contribution alludes to human beings' fallen condition. For this reason, one cannot construct a general concept of indulgence, because that will defeat the reasons of the purpose of existence through human history.

My hypothesis is that LaVey's Philosophy of Indulgence is a dogma-based assault on Scripture. This proposal does not mean that the philosophy under scrutiny is not based on life experiences at all, but 
that the main problem is figuring out the relationship between life experiences and the essence of our being as moral agents (Frankena 1995:1-5). Although LaVey utilises a sophisticated philosophical argument to describe Indulgence, he nevertheless offers a concept that can be applied with a moral conscience.

The second attribute is that, although LaVey's Philosophy of Indulgence does not hold a clear basis for the purpose of the existence of life (a concept that is traditionally believed), it is a good level of engagement in understanding the reality of the character of human beings as he engages in a chaotic sphere wherein nature plays a major role (McGrath 2001:131-139).

The importance of the people to whom LaVey's views appeal cannot be underestimated; the problem statement in this regard will be assessed in the light of the general church dogmatics standard and ethical positions. Here, I limit myself to the problem of the general concepts of fecundity, health and prosperity as the determining factors to the existence of life.

In order to give a balanced argument of the problem, I will look at several human problems that appeal LaVey's bias in respects to the modern sphere of understanding with regard to such issues as debt crisis, poverty, child abuse, corruption, war and many others. I have decided to consider the few aspects mentioned above, because in my opinion, they clearly highlight the problems caused by the absolute and exclusive use of Scripture. This is rather going to be one of the humble contributions to the challenges facing Christian dogmatics and ethical discourse in the fast changing world.

\section{THE INCEPTION OF THE PHILOSOPHY OF}

\section{INDULGENCE}

The Philosophy of Indulgence vis-à-vis a dogma based assault on Scripture opens an interesting field of study for the 21st century dogmatists. As Charles Darwin (1809-1882) stated:

I see new fields in the distant future for far more important researchers. Psychology will be based on a new foundation, that of the necessary acquirement of each mental power and capacity by gradation. Light will be shown on the origin of man and his history.

(Darwin 1999:399)

This important insight opens a line of what in my view should define Christian theology in the 21st century. It is evident that theology for the 21st century listener should have much more value than the previous centuries, because the essence of it should be founded on reality and through rational faith.

The authority of Scripture in this case has to be challenged by many factors today. This is because Scripture does not live just within the church any more, because if the church itself is open to being true to its own nature and vocation in the world, it opens up to the world of reality (Wright 1994:6-21). Truth therefore, is under scrutiny and even attacked. Everyday we can witness countless people whose Christian tradition shaped their moral life.

Today with the complexity of society that prophases aspects such as individualism, materialism and atheism are based on the current times which make it somewhat the time to revise Christian theology, that will not only be based on the Bible alone, but on the foundation of other components of social sciences that can inform the kind of teaching that will challenge people to understand the existence of life.

This pursues the line of reasoning of Prof. Johan Buitendag of the University of Pretoria in his inaugural address on 'Nature as Creation from an eco-Hermeneutical perspective: from a "Natural theology" to a "Theology of Nature"' where he stated, "The time is ripe for us to be able in an accountable way to arrive once again at a qualified natural theology' (Buitendag 2009:1). In his analysis of the term 'Natural Theology', Buitendag actually means a theology that answers the question of a purpose of existence of life that helps us to reach the transcendent God from below.

It is the explanation of human behaviour which can lead us into a full understanding of the transcendent God's involvement in the world. The definition of nature in LaVey's discourse simply means, 'that which is not polluted' by any teaching, dogma and or up-bringing, but operates within the instincts of life. For him, some people are born to indulge and others not. Those that are born to indulge in any action must do so and those to whom indulgence does not appeal should not (LaVey 1969:81-94). It is very realistic that the Christian has been a 'moral being' a curiosity without equal, as a 'moral being', more absurd, mendacious, vain, frivolous, harmful to himself than even the greatest despiser of humanity could have allowed himself to dream (Nietzsche 1979:102).

In saying this Nietzsche was probably very close to truth considering how humanity has tended to distort the Christian message for self gain. If we were to agree totally with Nietzsche's statements one would not hold any hope for the possibility that life could bring anything good with indulgence if there is no moral code. World disasters such as HIV/AIDS, poverty, unemployment, economic constraints are typical examples of people's failure to create a faithful and just world. If we were to totally deny Nietzsche's views, then we would be blind to the reality of human suffering in the midst of chaos which sometimes is caused by the Christian religion through its uncritical use of Scripture.

It is in the culture of human beings to create a standard of life even if lawbreakers will always be 'wolves in sheep skin': 'There are no people without a religion, much less without an ethic' (Nietzsche in Küng 2007:102). This implies that every ethnic group has quite specific values and criteria which are a creation of society. It is within this framework that Christian doctrines become part and parcel of the wider societal teaching.

It is a fact that Christian dogma has had a history of exclusion and condemnation rather than inclusion and encouragement (Bentley 2003:60-70). Nietzsche refuted Christianity because of this and commented on the Christian life, 'you will have to look more redeemed if I am to believe in your Redeemer' (Thielicke 1966:187). The stance of the church today reflects a closed orientation and they would struggle to associate with reality on earth.

Anton LaVey struggles with the church's exclusiveness, especially when he observes that the same Christians who proclaim redemption in Christ are the ones that find pleasure in indulgence (1969:13). LaVey uses the concept of indulgence to depict the manner of the freedom of choice that every human being has to celebrate life. This follows the argument that indulgence is a necessity because it provides room for nature to be the deciding factor and thus leaves no sense of guilt as it is a worldly philosophy $(1969: 81)$.

\section{WHO IS ANTON SZANDOR LAVEY?}

Anton Szandor LaVey is characterised by his questioning of religious doctrines which prevent people from facing the world of reality. He also opens a new way of looking at the philosophy of life through a secular world view. The argument he posits is that 'freedom to face reality emancipates human beings from hypocrisy and guilt consciousness that makes confessions of sins unnecessary' (LaVey 1969:13). In an introduction of the 2005 edition of LaVey's book The Satanic Bible, the new high priest, the Magus Peter Howard Gilmore, shares LaVey's journey of trying to make sense of the philosophy illustrated in Philosophy of Indulgence. This philosophy was formulated as a basis for his philosophical and religious discourse, eventually to become a pinnacle of debate after Lavey's death. 


\section{LaVey's birth and mission}

LaVey was born on 11 April 1930 in Chicago, Illinois to Jewish parents and died on 29th October 1997. Whilst he was still young, his parents relocated to California, the western most gathering place for the brightest and darkest manifestations of the 'American dream', according to LaVey (1969:14-17). From his Eastern European grandmother, young LaVey learned about the superstitions that was still existent in that part of the world concerning the power of magic. This provided him with a starting point in gaining interest into the study of human beings' behavioural changes. At the age of 36, LaVey became the American founder and High Priest of the Church of Satan. He also became a contemporary writer, occultist and musician. As the founder of a synthesised system of understanding of human nature, being influenced by the insights of philosophers who advocated materialism and individualism, LaVey gained ground. This formed a basis for a worldly philosophy.

LaVey's first public interaction, that would later initiate him into establishing the Philosophy of Indulgence, was through his musical abilities. These were noticed early in his life as he was given free reign by his parents to try his hand at various musical instruments. He found time to practice and could easily reproduce songs heard by ear without turning to sheet music (1969:18). This talent was his main source of income for many years. His talent also helped to usher him into playing for tent revivalists every Sunday. His odd interests, however, marked him as an outsider, but he could not alleviate it by feeling any compulsion to be 'one of the boys' (1969:19).

Moving beyond the standard texts, LaVey absorbed volumes of books analysing human behaviour on every level, from the impulses of the individual to the dynamics of society. His critical thinking and obsession with understanding human beings made him drop out of Globe High School in order to spend time studying people's behaviour at the carnival. He became well trained in many rackets used to separate the rubes from their money along with the psychology that leads people to such pursuits. This empirical study slowly started developing into something that would become a career.

In making some extra money for survival, LaVey decided to work for the police department as a photographer for a short period of time. During the Korean War, he enrolled in San Francisco City College with criminology as major. Both his studies and occupation revealed grim insight into human nature and confirmed his rejection of spiritual doctrines pursued.

In the 1950s LaVey became an investigator of alleged supernatural phenomena ('nut calls') referred to him by friends in the police department. This experience proved to him that many people were inclined to seek bizarre, 'other worldly' explanations for phenomena that had ordinary causes. His rational explanations often disappointed the complainants and so LaVey invented exotic causes to make them feel better. At this point, he gained insight in the functioning of faith in people's lives. A new chapter of his philosophical journey gradually started maturing.

To that effect, LaVey created a process of lectures to the general public towards an understanding of self through mental emancipation. When he began moving into a conceptual analysis of life in his explanation, a member of the public, satisfied with LaVey's views, suggested that Anton LaVey had a basis for a new religion. LaVey agreed and on 30th April 1966 decided to found the Church of Satan to enable him to communicate his ideas. The Church was initiated to later become a radical and controversial opponent to the Christian Church and its Scriptural doctrines as expressed in the nine Satanic Statements (LaVey 1969:25). By the end of 1969, LaVey took the monograph he had written to explain the Philosophy of Indulgence as a basis of emancipating people's consciousness (1969:17). This forms most of his reflections in The Satanic Bible.

\section{INDULGENCE ACCORDING TO ANTON}

\section{LAVEY}

Indulgence in the Webster's Dictionary is defined as 'to give oneself up to something'; 'not to refrain or oppose'; 'to give free course to'; 'to gratify by compliance' or 'to yield to something without being forced'. The meaning of the definition of indulgence implies that indulgence is an act on choices made by an individual in the absence of any dogma, peer pressure or superficial compulsion. When choices are made by a person they become that person's core to determine the standard of life they will lead, either in a positive or negative way. Human beings are subjects and objects of their choices, but these choices should flow naturally. Nature is thus deemed as a platform of indulgence because the foundation of our being is to make choices determined by our own understanding of life.

In the construction of the Philosophy of Indulgence, the highest plateau of human development is regarded as the awareness of the human nature' imbedded in the flesh with feelings and expressions (LaVey 1969:81-82). This differs with the animal kingdom in that animals can only sense the environment good for their species through natural instincts (Pannenberg 1970:15). When it comes to human beings, choices become the centre of all actions, but the choices made should only come with natural drives or instincts unique from the animals. It is the experiencing of internal expressions which should produce aspirations. When aspirations are attained, the meaning of life is complete. The argument here entails that the Philosophy of Indulgence figures out the reality of what satisfies human existence. LaVey (1969:81) indicates that lack of satisfaction builds harmful desires that would rapidly grow into compulsion, thus promoting a life of frustration. Therefore the ultimate goal of satisfaction is to discover the purpose of life. Satisfaction in this context means the accomplishment of all desires essential to achieve happiness.

In this regard I want take the human body as a case study which in the assessment of the Philosophy of Indulgence, simply expresses that which is natural within itself. According to LaVey, it is worth noting that people are primarily created natural beings in all spheres of life; therefore indulging in their natural desires are simply the fulfilment of the obedience to the Law of Nature. This implies that the goal of human beings is to find rest in nature, with no frustrations which can be harmful to themselves and other people. In a sense, this proposition of LaVey (about the human need for satisfaction) connects with Saint Augustine's reference to the 'human soul as restless till it finds rest in God'. It also links with Freud's emphasis on the id and the libido and human insistence for immediate need satisfaction. In the Philosophy of Indulgence, indulgence is the pursuit of the natural human fabric that brings about satisfaction.

The Philosophy of Indulgence argues that although the Christian Scripture has ultimate authority for a righteous living, its followers thrive on hypocrisy 'for the man's carnal nature overpowers even the most faithful' (LaVey 1969:21; 81-86). Nature, according to the Philosophy of Indulgence, is unavoidable and thus a response to that which is natural, is not a failure, but an accomplishment of the purpose for which nature exists. There are two words, which are referred to as cited outside context, 'indulgence' and 'compulsion'. Compulsion seen in perspective and in its context is never created by indulging, but by not being able to indulge as referred to earlier. This alludes to the fact that in compulsion there is lack of choice for one is simply compelled into performing an act. This is why LaVey contends that religious communities have caused chaos because people are compelled to act against their natural instincts (LaVey 1969:103). Dawkins (2006:294) in the same way argues that the world would have been better off without religion. In this context freedom of choice is at the heart of human satisfaction and not created dogmas or an ethical description of life. LaVey argues that making any kind of indulgence a taboo, it 'only serves to intensify the desire to 
indulge' (LaVey 1969:81-86). The underlying argument is that the ego of a human being has been prone to the things they have been told not to do, as illustrated by the proverb: 'Forbidden fruits are the sweetest'. Of course the question is to what extent can indulgence go without being unbalanced?

\section{THE DEVELOPMENT OF THE PHILOSOPHY OF INDULGENCE}

In this section I will look into the full details of the Philosophy of Indulgence according to LaVey. I will attempt to show that LaVey has a bias towards sexuality as a major faculty of indulgence. The Philosophy of Indulgence encompasses the sexuality issue. This marks Lavey's point of departure. I will consider some other areas of indulgence he refers to in his book The Satanic Bible as well. The next section of this article will deal with a response to his philosophy.

\section{Sexual indulgence}

Sexual indulgence and free love amongst human beings is dominant in LaVey's philosophy as expounded in The Satanic Bible. LaVey does not find any breach of a moral code as Scripture will clearly hold its position with regard to human morality not based on nature but on dogma. In the Philosophy of Indulgence love (desire) is the driving force for release. LaVey defines this force as 'a faculty of human existence that flows naturally in the life of human beings' (LaVey 1969:85). Love, sex and desire go hand in hand and they are considered free flowing aspects in the Philosophy of Indulgence. However, in respect of freedom, free love means exactly that - freedom of either being faithful to one partner or to indulge one's sexual desires with as many others as one wish, on condition that the act and desire flows naturally. Natural law in this matter is a prerequisite to indulgence. The implication is that indulgence discourages orgiastic activity or extra marital affairs for those to whom they do not come naturally. Unnatural indulgence in either extra marital affairs or to be unfaithful to a chosen mate if that does not flow naturally is detrimental as it does not enhance the emancipation of the mind The argument is that, for others who are naturally created to be sexually active, it would be frustrating to be bound sexually to just one person (LaVey 1969:84). Each person has a different orientation of sexual activity and thus every one must decide for themselves what form of sexual activity best suits their individual needs:

Forcing oneself to be adulterous or to have sex partners when not married, just for the sake of proving to others that they are emancipated from sexual guilt is just as wrong, by standards of indulgence.

(LaVey 1969:81)

With the subjective standards of indulgence, the most obvious aspect is that there should be no guilty feeling left because guilt hinders satisfaction.

This entails that those who are constantly preoccupied with demonstrating their emancipation from sexual guilt are in reality held in even greater sexual bondage than those who simply accept sexual activity as a natural part of life and who do not make a big deal over their sexual freedom (LaVey 1969:82). An example of an established truth is that 'every man's dream girl is not sexually free', but is actually frigid and moves from man to man because she is too inhibited to ever find complete sexual release (LaVey 1969:86). Herein lays two misconceptions of life which are highlighted to work as a basis for life. Firstly, the idea that the ability to engage in group sexual activities are indicative of sexual freedom and secondly that contemporary free sex groups have one common denominator vis-à-vis the discouragement of fetishist or deviant activities. The reality of LaVey's Philosophy of Indulgence is that if a person is a sexual connoisseur, that is, truly free from sexual guilt, they cannot be overpowered by any sexual revolutionists nor can they be stifled by prudery to develop into a quiet ridden society. Therefore the free sex clubs (such as brothels) miss the whole point of sexual freedom: 'Sex is a game of freedom and that freedom is a natural response to the human nature' (LaVey 1969:84). Unless sexual activity can be expressed on an individual basis, which includes personal fetishes, there is absolutely no purpose in belonging to a sexual freedom organisation which by and large merely produces a guilty conscience.

\section{Sexual orientation}

The Philosophy of Indulgence affirms that human existence cannot do things outside its natural instincts or drives within it. It is therefore a case of compliance with the naturalness of behaviour. Sexual orientation is natural behaviour which is determined by the natural make up of an individual. Jesus, when talking about celibacy affirmed that some people are born different than the expectation of society. He, for example, said that some people are born celibate whilst others are made by men to be so (Matthew 19:11ff). In the absence of any further explanation, the implication of this raises the question of being born with a particular sexual orientation which sometimes may not be the stereotypical expectation of society, for example, if one is born with a homosexual or lesbian orientation. In this case, the emancipation of the mind of a person, who discovers their natural orientation, can only be found when satisfaction is attained within the framework of their own genetic formation. Indulgence dismisses those who forcefully change or deny their sexual orientation to deal with their frustration, because it is basically unnatural (LaVey 1969:82ff). This entails that any type of sexual activity which properly satisfies one's individual desires (be it heterosexual, homosexual, bisexual, or even asexual desires) can be expressed with a free mind within natural operation. This comes to terms with any fetish or deviation which will enhance one's sex life, so long as it involves no one who does not wish to be involved. Rape, incest, defilement, amongst others, is therefore not natural activities and any one who does them, acts outside their natural framework.

La Vey (1969:84ff) maintains that everyone has some form of fetish, but because they are unaware of the prevalence of fetishist activity in our society, feel that they are deprived if they submit to their 'unnatural' yearnings. Human beings have weaknesses and strengths imbedded in their nature which cannot be explained. Paul in the letter to the Corinthians admits to this: 'whatever I want to do I don't do but whatever I don't want I find myself doing it' (Romans 7:21ff); this points to a study conducted amongst non-sexually active young people between the ages 16-25 years in Zambia in 2009 which revealed that a high percentage of the youth, who are called morally upright, experience a lack of opportunity for expression (Zambia Sexual Behaviour Survey 2009). For this reason, a number of these youths in this category resort to masturbation, child molestation and I believe rape at a later stage, against people who are physically not powerful enough to defend themselves. Many sexual desires never progress beyond the fantasy stage and that lack of release often leads to compulsion and therefore a great number of people devise undetectable methods to vent to their urges (LaVey 1969:81). Considering that most fetishist activity is not outwardly apparent due to lack of opportunity for expression, the sexually unsophisticated cannot be excluded from fetishist behaviour. LaVey alludes to the example of a fetish mentality where in, for example, the male transvestite will indulge in his fetish by wearing feminine undergarments whilst going about his daily activities; or the masochistic woman might wear a rubber girdle several sizes too small, so she may derive sexual pleasure from her fetishist discomfort throughout the day. In giving these examples, LaVey uses the law of indulgence as a prime factor in stating that any form of sexual expression is good and permissible as long as it hurts no one else. This affirms Socrates' appeal to the general moral rule or principle, 'we ought never to harm anyone in our actions' (Frankena 1995:2-5). Not hurting one another does not include the unintentional hurt 
felt by those who might not agree with your views on sexual orientation, because of their anxieties on sexual morality.

Sex in this case is perceived as a mature stage to be reached by mature adults who willingly take full responsibility for their actions and voluntarily engage in a given form of sexual expression, even if it is generally considered a taboo in most African societies. Sex for human beings is compared to food, as no two people are exactly the same in their choice of diet or have the same capacity for consumption of food. Sexual tastes and appetites vary from person to person. It is in this case that the Philosophy of Indulgence proposes that, no person and no society has the right to set limitations on the sexual standards or the frequency of sexual activity of another because it is a natural phenomenon. This directly contradicts the exclusive use of Scripture in transforming the world: 'Proper sexual conduct can only be judged within the context of each individual's situation' (LaVey 1969:66-67). For this reason LaVey (1969:103) says ‘What one may consider sexually correct and moral may be frustrating to another' (LaVey 1969:68). On the other hand, one person may have great sexual prowess, but it would be unjust to belittle another whose sexual capacity may not be equal to his own. It would therefore be inconsiderate for individuals to impose themselves upon another (e.g. the husband who has a voracious sexual appetite, but whose wife's sexual needs do not match his own needs). Varying sexual tastes and appetites need to be considered within the framework of marriage.

\section{Sex and marriage}

In the Philosophy of Indulgence, an ideal relationship is one in which two people are deeply in love with one another and are sexually compatible (LaVey 1969:81). Compatibility is a prime factor in an ideal relationship. However, it is worth noting that in the Philosophy of Indulgence developed by LaVey, perfect relationships are relatively uncommon following the human condition of nature in which men predominately are born unfaithful mates. LaVey argues that 'mutual love and sexual love can, but do not necessarily, go hand in hand' (LaVey 1969:70). If there is an amount of sexual compatibility then it is limited and not all sexual desires will be fulfilled in this case.

The bone of contention is that there is no greater sexual pleasure than that derived from association with someone you deeply love, if you are sexually well suited. In marriage the Philosophy of Indulgence entails that 'lack of sexual compatibility does not indicate lack of mutual love'. (1969:82). One can and often does, exist without the other. With this, one member of a couple will resort to outside sexual activity because he deeply loves his mate and wishes to avoid hurting or imposing upon his loved one. LaVey suggests that this owes to the fact that deep mutual love is enriched by sexual love and it is certainly a necessary ingredient for any satisfactory relationship; but because of different sexual preferences, 'it becomes ideal for a spouse to fulfil his sexual desires outside marriage' (1969:84-86).

Although the emphasis of indulgence in marriage only applies to a person who is not sexually compatible with his wife and turns elsewhere to find sexual satisfaction, the philosophy actually encourages sexual faithfulness to the chosen mate except where satisfaction is not attained. This idea suits best in African cultures where polygamy becomes a remedy for unfaithfulness.

\section{Life as fulfilment of the ego}

LaVey's philosophical discourse on death figures out the fact that humans are aware that they will die someday (LaVey 1969:46-48). This particular instinct prepares people for the hereafter. Animals, for example, when nearing death, know they are about to die; but it is not until the moment of death that the animal senses his coming departure from this world; even then the animal does not know exactly what dying entails. Animals accept death gracefully without fear or resistance.
When an animal is sick or injured, it will fight for its life with every portion of its strength. It is this unshakeable will to live that if humans were not so 'highly evolved', would also give them the fighting spirit they need to stay alive. In this case the value of life in the Philosophy of Indulgence is totally dependent on the operation of the ego. The ego, in this case, is a power house of present and future life. Life after death, according to the Philosophy of Indulgence, 'is a substance of the fulfilment of the ego and death being the only abstinence' (LaVey 1969:91-93).

It is a well-known fact that many people die simply because they give up and just do not care anymore. In Freudian terms, this corresponds with the death drive, or thanatos, in contrast to the libido, the principle of life. As a result of this, a number of suicides occur amongst people who are frustrated and whose sicknesses persist. Suicide has become less repugnant to many people than any other sin because the essence of this is the failure to fulfil human satisfaction.

In the Philosophy of Indulgence when a person dies, it is the greatest abstinence that provides freedom from indulging in bodily matter, but at the same time it is touted as 'a great spiritual awakening' (LaVey 1969:104), which is prepared for throughout an individual's life. In terms of the ego, it is this zest for life which will allow the vital person to live on after the inevitable death of his bodily shell. In other words, the Philosophy of Indulgence rightly acknowledges life after death, but that life is prepared for during the bodily shell period. This argument does not dismiss the Christian understanding of the end time and the hereafter.

The Philosophy of Indulgence emphatically states that 'life is one great indulgence, death the one great abstinence' (LaVey 1969:92). To a person who is satisfied with his earthly existence, life is like a party and no one likes to leave a good party. By the same token, if people are enjoying themselves here on earth, they will not so readily give up this life for the promise of the afterlife about which they know nothing. Anything that does not promote good, healthy, self-satisfaction or honest pride in earthly accomplishment, is against life (LaVey 1969:91-94). If, therefore, people were able to divorce themselves from the stigma attached to personal ego fulfilment, they would not need to play self deceitful games such as belief in re-incarnation as a means of satisfying their natural need for ego fulfilment. LaVey believes in 'complete gratification of a human being's ego' (1969:92-95) as a prime factor in understanding life. Fulfilment of life is intensified or encouraged by the ego. If a person's own ego is sufficiently fulfilled, one can state that a person can afford to be kind and to be complimentary to others without robbing himself of his self-respect. In this case, the ego results from a need to satisfy our own impoverished egos. If Scripture, however, wants to be a firm foundation then it should recognise the purpose of the ego. LaVey teaches that 'the development of a good strong ego is when it gives people self-respect necessary for life and have fought through to the end for their earthly existence' (1969:96ff). It is this ego which will refuse to die even after the expiration of the body which housed it.

Death comes as an indulgence because of the extreme circumstances which make the termination of life a welcome relief from unendurable earthly existence.

\section{THE MEANING OF LIFE}

In discussing the meaning of life as a response to LaVey's dogmatics of assault on life, I wish to raise a debate between LaVey and Moltmann on the meaning of life. Moltmann represents some of the dogmatic views of the church with regard to the eschatology of hope. For Christian dogmatics, human life does not refer only to a person being alive, but is identified in one's philosophy of life in totality (Moltmann 1996:49). This, in other words, includes the events of death and the state of existence in the hereafter. Life and death go hand in hand. One cannot live without dying and one cannot die without having 
been alive. Death in itself attains a certain meaning, pending our understanding of what is to follow. The one thing that unites all cultures and histories is the fact that we all have an understanding of life in the light of death. As opposed to Anton LaVey's synthesis that states that life is a fulfilment of the ego, life for a Christian is derived from how we make sense of the process from life to death and then in turn, to that which is beyond. It is how life, death and the hereafter are connected by our philosophies that determine whether we have succeeded in actually living in the first place.

Moltmann identifies two main responses to the question of life and death, describing those who live with the knowledge of death as a final destination and those who live as if death does not exist (Moltmann 1996:49-58). LaVey is probably close to the truth, when he states that if human beings could have an ego to fight through life to the end like animals, living can be ratified (LaVey 1969:78). Moltmann (1996:49) describes the first attitude towards the link between life and death by the question, 'is death the finish?' In the philosophy of life, life is a stepping stone in our existence. It is a gift of grace that is given to each individual, only to be confronted with the finitude of this gift in death (Moltmann 1996:51). Here death is seen as the final event of one's existence. The meaning of life therefore is a blessing from God and not the fulfilment of the ego because life itself portrays that which is beyond.

So when observing human behaviour, the perspective of observing life and death is perhaps the most natural:

Since in our consciousness we cannot perceive our own death and do believe in our own immortality, and allows us in the privacy and secrecy of our unconscious mind to rejoice that it is the next guy, not me.

(Kubler-Ross 1969:28)

In this case, we can say that a lifestyle that is focused on the present life can be described as being irresponsible and foolish.

Nietzsche, LaVey's philosophical mentor, identified the tendency of life and death in human behaviour by referring to those who hold this view as being in the grasp of Dionysus (Nietzsche 1995:5-7). By this he means that there are people who live their lives in captivity by their own passion without any regard for the future. The present is what matters now and the future will be dealt with when it arrives. Life then rests in the Kingdom of God and death cannot be more powerful than the state of our being for our human spirit is linked to the Divine Spirit (Moltmann 1996:72). The Kingdom of God is therefore neither transcendent, nor material in nature, but is to the individual the essence of experiencing the true and unconfined relationship with God in humanity. In this case, the greatest symbol of the temporal, namely death, cannot overcome the Kingdom as experienced in life, nor be its final destination (Hebblethwaite 1984:211)

In this one can conclude that the basis of understanding of our being rests on the Kingdom of God which is the ultimate goal of our existence.

\section{A CRITIQUE ON ANTON SZANDOR LAVEY'S PHILOSOPHY}

The critique on LaVey's Philosophy of Indulgence lies in the authority of Scripture and creation. Scripture is the basis for life, death and the hereafter. However, we need to ask where the Philosophy of Indulgence fits within the order of the cosmos and how it directly appeals to human instincts. Taking each argument into consideration one finds that there is a clear description of the concept of indulgence within each argument discussed in the previous chapters. An historical aspect of the human being has been investigated and some passages of Scripture have been discussed in response to the Philosophy of Indulgence. This section sums up the argument of the Philosophy of Indulgence as a dogma based assault on Scripture. Before engaging an assessment of LaVey's philosophy, one is tempted to ask: 'Is indulgence a real argument for today? If so, what value does it bring to the wholeness of life that awaits the coming of the Kingdom of God?'

\section{The critique}

In each of the previously discussed sections, indulgence is presented as the ultimate and complete goal of human existence in nature, whilst death is the ultimate abstinence. In my personal understanding indulgence is found in the grasp of chaos and the failure of humanity to accomplish the purpose of existence. This purpose of existence is found in our understanding of self, the world and God (Pannenberg 1970:41-71). Our openness to God and to the world opens a discourse that provides us with answers that can satisfy our being. Failure to discover this identity, results in us becoming prone to other projections that we would like to use as an antidote to our failures in life. In Scripture, the ultimate goal of our existence lies in the Kingdom of God, but of which LaVey said 'it is the fulfilment of the ego'. It is worth noting that the cosmos is a universal acceptance of things, regardless of their origin. Different emphases create the illusion that the universe consists of many different processes at work with different outcomes in mind. This is not LaVey's intention, as we find the common denominator of each of the proposed philosophies in other scientific explanations of nature as well.

The ultimate point and the fulfilment of the concept of indulgence is not found in the order of Scripture alone, but in areas of nature such as the history of human beings, our genetic make-up, our cultures and traditions. These enhance a unified, holistic understanding of life.

\section{LaVey's Philosophy of Indulgence}

The term 'indulgence' is not an adequate description of what LaVey is trying to convey. It is a term that is filled with questions that may not even be relevant to the discussion around the essence of our being. Of course, the process that theologians and those who submit themselves to modalism use would encourage the inclusion of this concept in any theology (philosophy) of nature although my argument is that LaVey's philosophy undermines the question of human dignity and morality within the evolved cultures that respond to the sense of belonging to God.

The question can be posed as to whether or not we really need satisfaction through indulgence as a means to an end. Or are we incomplete without indulgence? Any suggestion that people are in a process of self advancement denies the dignity and role of human beings in the cosmos. It is disappointing that LaVey does not give sufficient explanation of the philosophy in The Satanic Bible. He does not actually develop a concrete argument that highlights an improved being, but is concerned solely with human beings as a part of creation.

In LaVey's philosophy the relational concept is between human beings and creation. LaVey does not present his philosophy in a manner that addresses the redeemed part of humanity. In his argument an act of salvation or hope in God cannot be found, but he promotes merely the existential experience of life within the natural realm, specifically human satisfaction as the ultimate goal of existence. I would have probably been more satisfied if he considered looking at the role the covenant plays between God and creation in the created order. Jürgen Moltmann in his book The Coming of God (1996) asks the question: 'What is the purpose of creation as we find it in its original relational state with God?' In other words, 'Where are we going?' It is quite evident that in Christian eschatology (as it is with many philosophies) the search of the meaning of life is ideal. We are actually looking for our end result which should focus on the glorification of the transcendent God as the ultimate purpose 
of Creation (Moltmann 1996:323), but at the same time the meaning of life and the hereafter. LaVey looks at glorification as a satisfactory mark for human beings, whose satisfaction is found in indulgence which is considered to be the emancipator.

The main understanding of the character of nature is to be found in the creation narrative in Genesis 1 and 2, which should be understood in the very context of creation. In the beginning there was 'chaos', that is, confusion. Disorder in this sense will mean not having any form that can be helpful to enhance understanding. Indulgence therefore fails in this pinnacle of creation for it has no conscience of any kind: 'God is the only hope for creation (Moltmann 1996:329). This means that God should be travelling alongside creation. This understanding assumes two theological 'developments' in creation's realm, that is, God relating to his creation through self-revelation, which by and large provides an insight for moral obedience and secondly, the uniqueness of God being part and parcel of his creation.

\section{CONCLUSION}

The starting point in confronting the dogmatics of assault should begin with honestly facing the meaning of life and the development of human beings. There is a reason for everything, as is evident in the history of human development; every created thing depends upon the other. This concept applies to all biological discoveries, where each object is a parasite of the other and the reality of it is only found at the end. In reading Moltmann's doctrine of creation in relation to LaVey's Philosophy of Indulgence, one finds the biggest display of direction within a theological framework: 'Human beings live for the future hope' (Moltmann 1967:228). In living for the future, I do not mean man is excluded from the world of his creation. This world will always play an important role as humanity's platform for its procreative nature (Pannenberg 1970:15). The real dogma of reality in this case is that which recognises humanity as living and existing within the horizon of history in nature (Moltmann 1967:289). As much as I may not agree with LaVey on most issues regarding his perception of nature in human beings as a prime factor for indulgence, nature itself is a starting point in confronting a dogma that answers people's questions. If the meaning of life is to be attained, there must not be a distinction between humanity and the rest of creation. People need creation in order to realise the Kingdom of God and creation needs people to be perfected and conformed to the likeness of God. This is expressed in Paul's writing to the Romans that 'creation groans for the sons of God to be revealed for its redemption' (Romans 8:18ff).

In the light of aforementioned arguments, the Philosophy of Indulgence lacks in its understanding of Scripture. Scripture in its totality teaches an ethic of love that is both transcendental and immanent. Scripture shows the way in which the believer should live and have a connection of the sense of that connection with our creator. I am convinced that nature really plays a role in our understanding of God, but it is only when we are able to recognise God in nature that satisfaction is made complete. The whole journey should be imbedded in the Kingdom of God.

Because Scripture and its authority cooperate to create an ethic of life, there is a distinctive feature to hold on to. People look for it in vain if they seek it abstractly in some idea or principle, some disposition or a new dispensation of 'Love and freedom'. There are indispensable tenets of Scripture and we ought to live by them, but at the same time protest against the background of a 'creation of consummation'. But what then is the criterion of Scripture which LaVey in his analysis of the Philosophy of Indulgence does not comprehend? There is not an abstract, but a Godly purpose in creation whereby theology, or a theocentric system of thought, grants us the meaning of life. There is a vividness of the God of history who is not foreign to our being. Our actions are known to him. Indulgence can never be the ultimate satisfaction, because nature solely depends upon the God of Scripture.

In this regard, Anton Szandor LaVey's Philosophy of Indulgence only seeks to assault Scripture; therefore, I view it as a dogma based assault on Scripture. I am convinced that our nature which is based on God's good creative activity will by and large be the ultimate platform to understand God and therefore relate to Him.

\section{REFERENCES}

Bentley, W., 2003, 'The Kingdom of God in Moltmann's Eschatology: A South African Perspective', unpublished M dissertation, Dept. of Dogmatics and Christian Ethics, Faculty of Theology, University of Pretoria, South Africa.

Buitendag, J., 2009, 'Nature as creation from an ecohermeneutical perspective: From a "natural theology" to a "theology of nature", HTS Theological Studies 65(1), Art. \#272, 10 pages. DOI: 10.4102/hts.v65i1.272.

Darwin, C., [1859] 1999, The Origin of Species, Bantam Books, New York.

Dawkins, R., 2006, The God Delusion, Bantam Press, Great Britain.

Frankena, W.K., 1995, Ethics: Foundations of Philosophy Series, 2nd edn., Prentice Hall, New Jersey.

Gilmore, P.H., 2005, Introduction in LaVey, S.A., 1969, The Satanic Bible, Harper Collins publishers, New York.

Hebblethwaite, B., 1984, The Christian hope, Eerdmans Publishing House, Grand Rapids.

Kubler-Ross, E., 1969, On Death and Dying: What the dying have to teach doctors, nurses, clergy and their own families. Touchstone publishers, New York.

Küng, H., 2007, The Beginning of All things, William B. Eerdmans, Grand Rapids.

LaVey, S.A., 1969, The Satanic Bible, Harper Collins Publishers, New York.

McGrath, M., 2001, Demons of the Modern World, Prometheus Books, Amherst.

Moltmann, J., 1967, Theology of Hope, transl. J.W. Leitch, SCM Press, London.

Moltmann, J., 1996, The Coming of God: Christian Eschatology, transl. M. Kohl, SCM Press, London.

Nietzsche, F., 1979, Ecce Homo, transl. R.J. Hollingdale, Penguin Classics, London.

Nietzsche, F., 1995, The birth of tragedy, transl. Clifton P. Fadiman, Dover Publications, New York.

Pannenberg, W., 1970, What is Man: A Contemporary Anthropology in Theological Perspective, transl. Duane A. Priebe, Fortress Press, USA.

Thielicke, H., 1966, The waiting Father: Sermons on the parables of Jesus, transl. J.W. Doberstein, James Clarke and Company, London.

University of Zimbabwe, National HIV/AIDS/STI/TB Council, 2010, Zambia Sexual Behaviour Survey 2009 by the Central Statistical Office, Ministry of Health -Measure evaluation, retrieved n.d., from http://www.phishare.org/files/8981_ tr_10_73.pdf

Wright, N.T., 1994, The Last Word: Scripture and the Authority of God - Getting Beyond the Bible, Harper San Francisco Publishers, United Kingdom. 